\title{
A mixed-method approach for the assessment of local community perception towards wind farms
}

\author{
Paula Ferreira* \\ Centro ALGORITMI, Escola de Engenharia, Campus Azurém, 4800-058, Guimarães, \\ Portugal \\ email: paulaf@dps.uminho.pt \\ Fátima Lima \\ Centro ALGORITMI, Escola de Engenharia, Campus Azurém, 4800-058, Guimarães, \\ Portugal \\ email: lima.mfatima@gmail.com

\section{Fernando Ribeiro} \\ Centro ALGORITMI, Escola de Engenharia, Campus Azurém, 4800-058, Guimarães, \\ Portugal \\ email: fernandor@dps.uminho.pt
}

\section{Filipa Vieira}

Centro ALGORITMI, Escola de Engenharia, Campus Azurém, 4800-058, Guimarães, Portugal

email: filipadv@dps.uminho.pt

\section{*Corresponding author}

\section{Abstract}

The implementation of wind power projects can have significant impacts on local communities. If on one hand the project can bring important economic benefits, on the other hand it can represent a source of conflicts and discontentment. This paper aims to revisit this topic, addressing impacts and their perceptions from the local community point of view. A mixed method approach was proposed and implemented in a Portuguese region (municipality) used as case study. Semi-structured interviews directed towards local stakeholders were conducted to evaluate the acceptance of these wind power projects and the perceived impacts. The qualitative study was subsequently 
complemented and validated by a quantitative approach, through a questionnaire targeting local population. In general, the collected opinions seem mainly driven by the perceived socio-economic benefits resulting from wind farm deployment, with generally positive attitude towards wind farms. Identified local positive impacts include "community funds", "benefits in kind" and "indirect local employment". The key role of benefit sharing mechanisms on ensuring public acceptance and effective local 42 development is confirmed.

Keywords: Wind power; interviews; questionnaire; community; impact assessment.

\section{Acknowledgements}

47 The authors wish to acknowledge the support of ALGORITMI research Centre at 48 University of Minho. This work has been supported by COMPETE: POCI-01-0145FEDER-007043 and FCT - Fundação para a Ciência e Tecnologia within the Project Scope: UID/CEC/00319/2013.

\section{Introduction}

Overall energy is a driving force for social wellbeing, and particularly renewable energy sources (RES) projects have brought important changes to national energy systems but also to local communities. Several studies have been addressing the topic of local and community social aspects of RES projects but the topic is still far from being fully explored. A thorough research on the public perception on local development brought by these projects, more specifically of direct and indirect benefits and negative effects to

60 hosting communities is still required, as this represents fundamental information for both 61 investors and energy policy makers.

62 The perception of wind power impacts and social acceptance is highly dependent on the 63 cultural and socio-economic conditions of the local population and the planning of these projects is influenced by multiple conflicting interests and values (Ek and Matti, 2015). As Aitken (2010a) highlighted, there is merit in understanding public attitudes and 
67 participation can produce positive outcomes and opportunities to improve planned 68 developments.

69 The importance assigned to employment generation is well demonstrated in the literature with different studies addressing this as a major potential socio-economic benefit of RES development (see for example Sooriyaarachchi et al, 2015 and Ortega et al, 2015) but still suffering from significant uncertainties (Camerona and van der Zwaan, 2015). In addition, benefits such as community funds and project ownership are also discussed given the possible role of RES projects on improving socio-economic welfare in isolated rural areas (del Rio and Burguillo (2010); Munday et al (2011) and Allen et al, 2012). However, several factors contribute also to local resistance and opposition towards such projects such as concerns about health, noise, shadow flicker, aesthetics, loss of place identity or potential loss in property value (Khorsand et al, 2015).

Ek and Matti (2015) work on local impacts of large scale wind park planned to the northern Sweden demonstrated concerns on external costs for the local community both related to sustained nature conservation and local economic activities, namely reindeer herding. Also for northern Sweden, Ejdemo and Söderholm (2015) concluded on the existence of significant local impacts on construction jobs for wind power projects but put also in evidence the importance of benefit sharing mechanisms to generate positive impacts on employment rates during operation phase. In fact, benefit sharing can be of major importance for social acceptance, generating additional socio-economic benefits from the re-investment of the revenues. In line with this, several studies pointed to the importance of perceived benefits brought from direct economic gains to local communities (e.g employment opportunities) but highlight also the benefits generated from funds offered to affected communities, aiming for the fair distribution of earning and to the promotion of acceptance of hosting communities (Khorsand et al, 2015). Okkonen and Lehtonen (2015) focused on wind power projects in Northern Scotland and found that strategic re-investments of revenues in local social services can generate several times more employment and income compared with the impact of wind power production. Equally distributed regional benefits is then an important measure to increase local acceptance of wind energy projects (Walter, 2014).

97 Although in developing countries the public seems to give particular attention to the possibility of industrial development yield economic benefits, perception of negative externalities such as noise or visual impact play also an important role on these emerging 
100 economies (Guo et al, 2015). Gorayeb and Brannstrom (2016) argued that wind farms 101 can cause large impacts on the environment and traditional livelihoods of local residents 102 in Brazil and underlined the importance of management of benefits generated by wind 103 power on local communities. In line with this, de Sena et al (2016) also concluded that 104 the positive vision towards RES and wind farms in particular is mainly related to the 105 perception of positive local socio-economic impacts in Brazil, but showed that the 106 population is highly sensitive to the environmental impacts. The importance of economic 107 factors was also demonstrated for European countries. Frantál (2015) showed that the 108 significance of visual impact is outweighed by perceived socio-economic benefits for municipalities in the Czech Republic and Ribeiro et al (2014) concluded that at local level

110 the economic revenues flowed to the populations largely contributed to the RES 111 acceptance in Portugal.

112 A previous study from Ribeiro et al (2014), on the social acceptance and for renewable 113 energy sources in Portugal indicated a general positive attitude towards wind power. The 114 authors even concluded that residents in municipalities where wind power plants are 115 already operating can be more supportive than residents living in municipalities with no 116 installed wind farms. This positive attitude can be to some extent explained by the 117 perception of contribution for development of local population. The case of Portugal was 118 also analyzed by Delicado et al (2016) focusing on case studies of communities living in 119 the vicinities of three wind farms with the authors concluding on the heterogeneity of the 120 community perceptions and also on the significant levels of indifference towards these 121 facilities even for residents living nearby. Nevertheless, concerns about environment 122 including animal welfare and noise complaints were also reported and opinions on 123 landscape change were ambivalent. However, national positive attitudes should not be 124 seen as a guarantee of high local acceptance (Walter, 2014; Khorsand et al, 2015) and the 125 success of wind power requires a better understanding of the so called "social gap" (Bell 126 et al, 2005). Further studies on local impacts, perception and willingness to accept new 127 wind farms are then required under a sustainable energy planning perspective.

128 The proposed work aims to contribute to this debate on the perceived local and regional 129 impacts of wind power projects as fundamental drivers' for local acceptance. A mixed 130 methodology is proposed to assess these impacts from a stakeholder's perspective and 131 overall public opinion. The proposed methodology is then tested and applied to a 132 Municipality case study with the objective of both demonstrating its potential 
133 implementation process and to draw conclusions on the local and regional perceived 134 impacts of these projects in Portugal.

135 The case of Portugal is particularly interesting to be analyzed given the high level of RES

136 contribution in the electricity system and also given the particular characteristics of these

137 projects, frequently located in less developed regions of the country with a declining and

138 ageing populations. The proposed approach is focused on a particular municipality with

139 the above mentioned characteristics and although the results may not be generalized to

140 all municipalities, are expected to give an important contribution to understand some of

141 the social aspects of wind power under the Iberian context.

\section{Case Study}

144 Portugal has been considerably dependent on external energy resources, mainly due to 145 energy system's reliance on fossil fuel (oil, natural gas and coal) (DGEG, 2015). In order

146 to reduce the country's external energy dependence, while increasing energy efficiency

147 and reducing $\mathrm{CO}_{2}$ emissions, the national government has developed strategic guidelines

148 for the energy sector promoting energy efficiency and stimulating the contribution of 149 RES, focusing on wind energy, among others (National Plan for Renewable Energies and 150 National Plan for Energy Efficiency, last version available on Presidência do Conselho 151 de Ministros, 2013). Wind power currently represents a key technology in the national 152 energy context. By the end of 2015, installed wind power represented $26 \%$ of the total 153 installed power of the Portuguese electricity system and its power output contributed to 154 meet $23 \%$ of the total electricity demand of the country (REN, 2015).

155 Both qualitative and the quantitative studies described in the paper were developed in the 156 same rural municipality (for confidentiality reasons the municipality will not be 157 identified) located in the north region of Portugal in the district of Vila Real, a region characterized by the high density of wind turbines, as shown in Figure 1. 


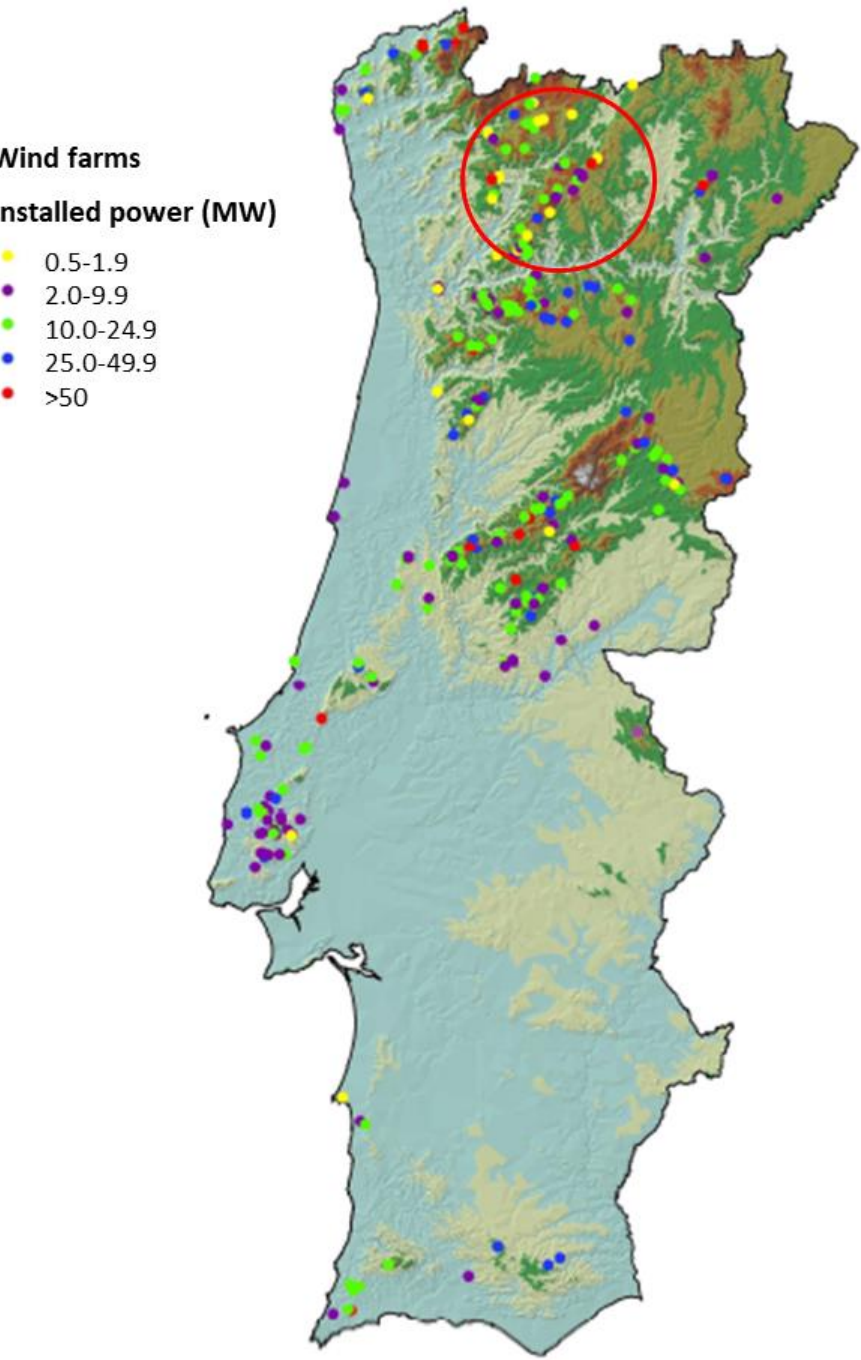

162 Vila Real district has more than 20 wind power farms connected to the grid and is the 163 second district with the highest installed wind power in the country reaching a total of $164658 \mathrm{MW}$ (INEGI, 2015). The population of the municipality is about 13200 residents 165 although in the quantitative study only close to 9600 habitants were considered as those 166 were the ones living in parishes (in Portuguese freguesias) where wind farms are already 167 operating. This region could be described as having "disperse population" distribution, 168 with a pronounced declining pattern due to above mentioned reason, as well as an 169 increasing growth of elderly population. The cited characteristics, along with other factors 170 such as the reliance on agricultural activities, the high unemployment rate, the land 171 availability and the favorable wind characteristics make these areas particularly well 172 suited new project's development. 
173 In order to assess the perception of socio-economic benefits and costs at a regional and 174 local scale, a case study for the described region was developed. Because wind turbines 175 have been or will be installed in communal ground, which management is delineated by 176 the Portuguese Legal Resolution $n^{\circ}$ 68/93 through the institution of Communal Land 177 Commission Councils, the selected research participants for the qualitative approach were 178 representatives from these same Commissions. This focal group was considered ideal for 179 exploring local impact from RES projects because they have been present throughout the 180 entire negotiation process and established the links with other key players, namely RES 181 promoters and local population. This exploratory approach was supported by semistructured interviews and was expected to bring considerable information about the perception of the population, the acceptance and the social impacts.

184 Although current legal framework established that $2.5 \%$ over total energy generation 185 income from a wind farm should be assigned to the local municipalities (Decree-Law 186 339-C/2001), other benefits obtained from wind farm projects were also discussed with 187 the interviewed from the Communal Land Commission Council. Discussing with 188 stakeholders this negotiation process directly contributes to the outlined objectives of the 189 research, regarding what are the main impacts and how they are being perceived. Overall 190 within stakeholders group, the focused participants had a good knowledge of local reality 191 given their positions and due to their responsibilities, despite having different professional 192 backgrounds. Most backgrounds ranged from three of the most preeminent local 193 activities, such as construction workers, farmers or shepherds to engineers, accountants, 194 bank account managers, contributing to diversified perceptions of wind energy 195 deployment.

\section{Methodology}

199 Mixed methods approaches can combine different methods targeting the evaluation of 200 impacts of projects, technologies or programs and allowing to integrate social quantitative 201 and qualitative approaches to theory, data collection, data analysis and interpretation

202 (Bamberger, 2012). Bamberger (2012) pointed out that mixed methods approach can 203 result in an enhancement of validity or credibility of evaluation findings and allows to 204 strength the representativeness of in depth qualitative studies by linking a case study to quantitative sampling. 
206 Even though quantitative approaches, and particularly questionnaires, seem to prevail 207 when assessing public perception regarding RES projects (Ribeiro et al, 2011), their 208 disadvantage lies precisely on its inability to fully assess the social dimension with 209 incomplete data collection and difficulties on results interpretation (Bamberger, 2012). 210 Conversely qualitative approaches have been perceived as being appropriate to assess 211 public perception taking into consideration the complexities of public opinion (Aitken, 212 2010a). However, as Bamberger (2012) pointed out qualitative approaches also present 213 weaknesses such as the lack of generalizability, difficulties on reaching consensus and 214 apparent subjectivity. Combining both qualitative and quantitative approaches can then 215 bring new insight to the impact evaluation directed towards the case of RES technology 216 in a particular region.

217 In previous works, this mixed-method proved to be useful to gain a thorough insight of 218 social aspects influencing wind power deployment (Del Rio and Burguillo, 2009; Munday 219 et al, 2011 and Rogers et al., 2008). However, this issue has not been comprehensively 220 addressed in the Portuguese case before for the case of assessment of local perception of 221 impacts of wind farms. A few recent examples for Portugal include Delicado et al. (2016) using interviews with residents to assess community perceptions of the impact, both positive and negative of wind and solar farms, Botelho et al (2016) using questionnaires directed towards residents to provide some insights on the compensation for damage sustained for wind, forest, solar and hydro power plants and Ribeiro et al (2014) using large scale surveys on public acceptance of renewable power (wind, solar, biomass, hydro) and underlying motivations for the Portuguese population.

228 To the best of the authors' knowledge the use of a mixed method approach for the analysis 229 of the impacts perception of RES projects on a particular municipality is not yet attempted 230 in Portugal. The present case study was then developed in order to assess the potential 231 socio-economic benefits or disadvantages at a regional and local scale. Both interviews 232 with local stakeholders directly involved in the negotiation phase for the wind farm 233 implementation and in the management of communal benefits (qualitative approach) and 234 questionnaires to local population (quantitative approach) were conducted followed by 235 the statistical analysis.

236 The use of interviews with open-ended questions is justified with the objective of bringing out rich and meaningful answers and allowing greater spontaneity and adaptation of the interaction between the researcher and the interviewed (Mack et al, 2015). This study 
239 included 7 interviews and counted with the support of a local resident as a facilitator for

240 the contacts. This local facilitator acted as an interface between the researcher and the

241 local community, by referring potential participants to be included in the interview

242 process and allowing to gain access to groups that would otherwise be inaccessible,

243 through any other means (see Rubin and Babbie, 1997; Hale and Astolfi, 2007). The main

244 selection criteria underlying this specific case, lay on four premises:

245 - All participants of the stakeholder's group (hereafter called interviewees) are members

246 of the local community;

247 - All interviewees are members of the Council Commission, who are elected by the

248 community for representation, management and inspection purposes;

249 - These interviewees closely followed the wind power project to safeguard that local

250 communities' interests were well understood and considered by the promoters;

251 - As members of the community, the interviewees may have themselves both direct and

252 indirect benefits or complaints related to the wind power project.

253 Due to the exploratory nature of qualitative research, accurate and detailed insights

254 resulting from interviews with the stakeholders were subsequently complemented and

255 validated by quantitative methodology, through application of telephonic questionnaires.

256 These questionnaires were applied considering the geographical division parish, which is

257 a subdivision of Municipality in Portugal. Wind farms are located in nine parishes of the

258 selected Municipality, totaling 9583 inhabitants according to the last Portuguese census

259 (censos.ine.pt, consulted on March 2013). The CATI (computer-assisted telephone

260 interviewing) allowed to collect 353 valid responses resulting reaching a 95\% of

261 confidence interval and $5.1 \%$ of margin of error. Details of the questionnaire are present

262 in Table 1.

263

264 Table 1 - Questionnaire outline

\begin{tabular}{|l|l|}
\hline Survey period & May $\mathbf{2 0 1 3}$ \\
\hline Population & 9583 inhabitants \\
\hline Respondents & 436, among which 353 were considered valid \\
\hline Method & CATI (computer-assisted telephone interviewing) \\
\hline $\begin{array}{l}\text { Questions and } \\
\text { response codes }\end{array}$ & $\begin{array}{l}\text { 1. Have you heard of wind farms or electricity produced from the wind? (Filter question; only those who } \\
\text { respond positively may proceed). } \\
\text { Yes } \\
\text { No }\end{array}$ \\
\hline
\end{tabular}




\begin{tabular}{|c|c|}
\hline & $\begin{array}{l}\text { 2. Do you believe that wind power brings benefits to the community? } \\
\qquad \begin{array}{l}\text { Yes } \\
\text { No }\end{array}\end{array}$ \\
\hline & $\begin{array}{l}\text { 2.a (Only if response to question } 2 \text { was positive): Please specify the most important benefit. } \\
\text { Rent from communal land } \\
\text { New roads } \\
\text { New social infrastructures } \\
\text { Job creation } \\
\text { Others }\end{array}$ \\
\hline & 3. Do you believe that wind power brings disadvantages to the community? \\
\hline & $\begin{array}{l}\text { 3.a (Only if response to question } 3 \text { was positive): Please specify the most important disadvantage. } \\
\text { Visual impact } \\
\text { Noise impact } \\
\text { Impact on agriculture, shepherding or other economic activities } \\
\text { Others }\end{array}$ \\
\hline & $\begin{array}{l}\text { 4. What was your position towards the construction of the wind farm, before its implementation? } \\
\qquad \begin{array}{l}\text { Favorable } \\
\text { Against }\end{array}\end{array}$ \\
\hline & $\begin{array}{l}\text { 5. Did your position towards the wind farm change after its implementation? } \\
\qquad \begin{array}{l}\text { Yes } \\
\text { No }\end{array}\end{array}$ \\
\hline
\end{tabular}

\section{Results of the quantitative analysis}

268 The first question acted as a filter, with the objective of allowing only respondents that were aware of the technology to proceed until the end of the questionnaire. This question had to be very clear even for respondents with low educational degree, so respondents were asked "have you heard of wind farms or electricity produced from the wind?" A proportion of $81 \%$, or three hundred and fifty-four (354) respondents passed the filter question.

274 The second question, "did the wind farm bring benefits to the community", received

$27556.5 \%$ of positive answers, against $43.5 \%$ negative ones. Taking into account the sample

276 size, it can be said that the number of respondents who believe there are benefits is 277 statistically significantly higher than those who believe there are no benefits. It was found 278 that respondents with a positive view towards the wind farms are younger (t-test, $279 \mathrm{p}=0.002$ ) and have higher education (Wilcoxon-Mann-Whitney $U$ test, $\mathrm{p}<0.01$ ).

280 The respondents who answered positively on the benefits were asked to specify the most 281 important benefit. The most mentioned one was job creation, while the least mentioned 
282 was investment in social infrastructure (such as daycare centre, cemetery or other 283 facilities). Results are presented in Figure 2.

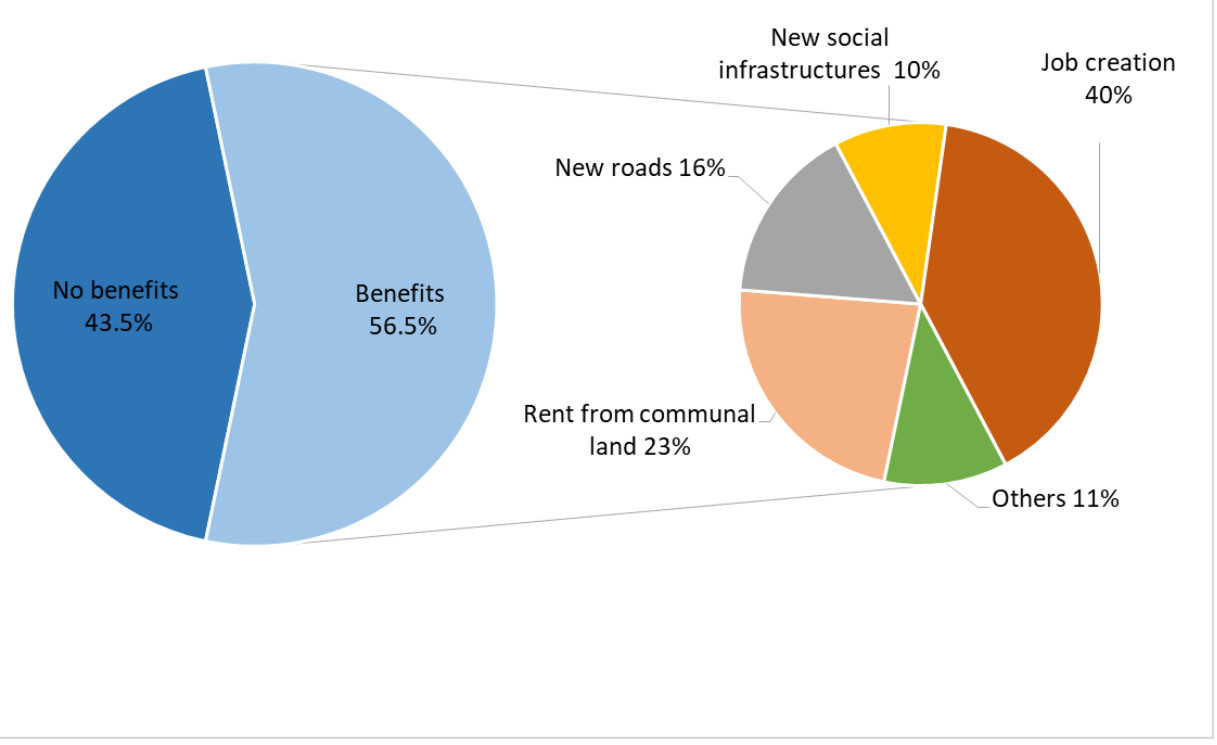

Figure 2- Distribution of most relevant benefits by public opinion.

286 It was found that the number of times that males refer to job creation is statistically 287 significantly higher than females' references (Fisher's exact test, $\mathrm{p}=0.005$ ), along with 288 respondents with higher education (Wilcoxon-Mann-Whitney $U$ test, $\mathrm{p}=0.001$ ).

289 The question "did the wind farm bring disadvantages to the community" received a much 290 more negative proportion of answers (70\%) than positive ones (30\%), therefore also a 291 statistically significantly higher number of respondents believe there are no disadvantages 292 to the community. Age, gender or educational degree do not have statistical significance 293 on these results. Among those who perceive the existence of negative impacts, $66 \%$ 294 responded that noise was the most important issue. Results are presented in Figure 3 with 295 more detail. The respondents who chose "noise" have no clear tendency of age, gender 296 or educational level. 


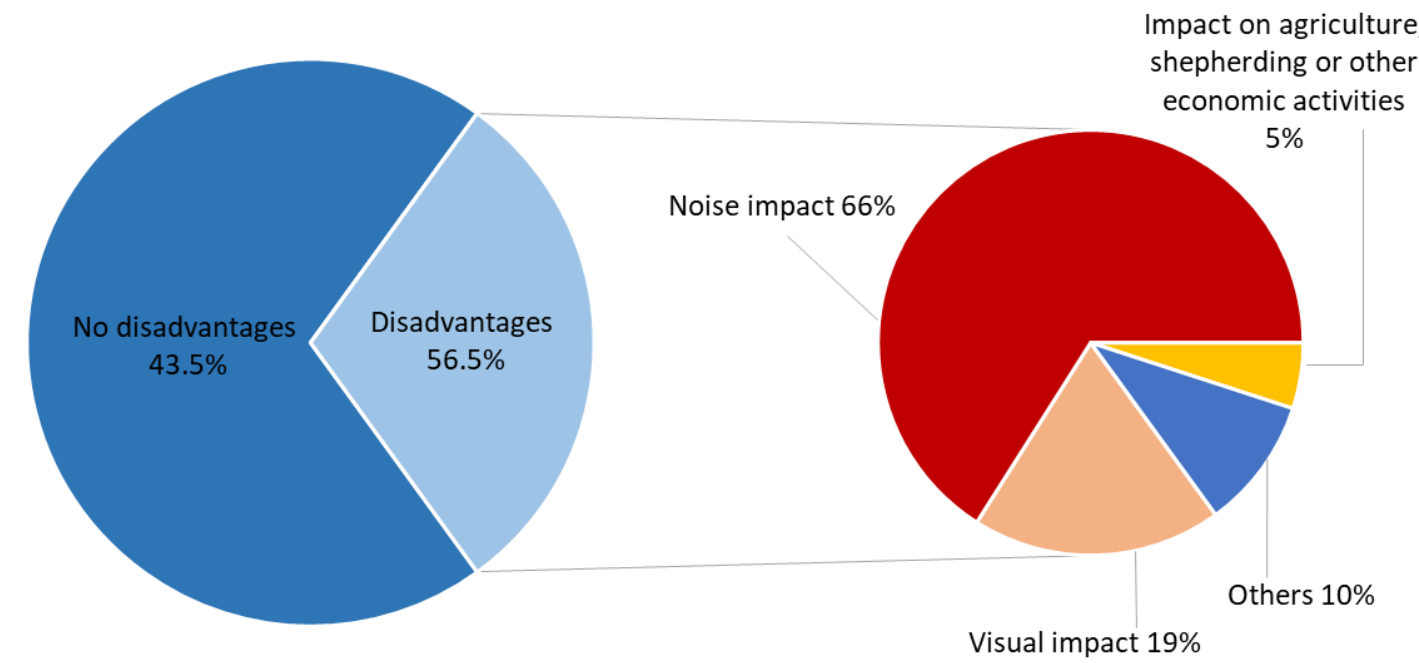

Figure 3- Distribution of most relevant adverse effects by public opinion.

300 The majority of respondents corresponding to 169 or $51 \%$ was favorable to the 301 construction of the wind farm before its construction, 127 or $39 \%$ were neither for or 302 against the farm, and $33(10 \%)$ were against. Ignoring those who were neither for or 303 against the construction, statistically significance tests (Wilcoxon-Mann-Whitney U test, $\mathrm{p}=0.015$ ) suggest that respondents inclined to agree with the construction of the farm possess a higher educational degree.

306 After the farm was built, only 23 of those who were favorable (roughly 14\% of the 169)

307 changed their opinion. Among these 23, only 12 of them believe the wind farm brought 308 disadvantages (10 mentioned noise, 1 visual impact and 1 "other"). These 23 who 309 changed to a negative opinion have a statistically higher education (Wilcoxon-Mann310 Whitney $U$ test, $p=0.035$ ) than the rest of the respondents. On the other hand, 5 311 respondents, roughly $15 \%$ of the 33 who were against the wind farm and changed their 312 opinion to a positive one. Three of them believe the farm has brought benefits: two of 313 them mentioned job creation and one mentioned land rent.

314 We can conclude that the public opinion in the area where the survey was collected is 315 characterized by a generally positive attitude towards wind farms. As seen, although in 316 absolute numbers, more respondents gained a negative opinion towards the wind farm 
317 after it was built, in relative terms it is roughly the same percentage of respondents (15\%

318 vs. 14\%) changing their opinion towards a positive one.

\section{Results of the qualitative analysis}

The importance of preliminary impact analysis and planning for determining an ideal location for wind farms, therefore promoting its integration in the surrounding environment is highlighted in studies such as Mendes et al, (2002) or Watson and Hudson (2015). As such, this section is based on a previous revision of the literature to summarize positive and negative impacts on wind farms (Lima et al, 2013) which were then discussed with the interviewees for the specific case under analysis. This review, especially in what concerns social issues, showed that despite the increasing relevance of the theme, social dimension is far from being fully explored. Yet, the main social aspects which were considered to be particularly relevant for the region under analysis have been analyzed, generally focusing on employment generation; community funds and benefits in kind.

331 For the sake of simplicity, the analysis of the qualitative study (interviews with

332 stakeholders) will be divided in two main aspects namely, the perception of positive and 333 negative impacts.

\subsection{Stakeholder's perceptions of positive impacts}

Regarding positive impacts overall most interviewees viewed this investment as positive for local communities, with a wide assortment of benefits being distributed according to different categories of community benefit schemes, encompassing "community funds", "benefits in kind", or "local employment" (see Table 2).

341 Interviewees have mentioned unanimously as main advantages several aspects within the

342 main available categories, which were, as interviewee statements attest, highly 343 interconnected. For instance, additional revenues resulting from annual rent within 344 "community funds" were closely connected to accessibility provision and improvement and social infrastructure within "benefits in kind" which is interlinked to "local employment" category, as Interviewee's 1 and 5 emphasized. 
347 Nonetheless, a full overview of the most mentioned benefits checklist has also highlighted

348 less consensual aspects such as reforestation or tourism within "benefits in kind",

349 reflecting different perspectives within stakeholder's perception regarding re-investment

350 and diversification of attained revenues as expressed by Interviewees 1 and 2 quotes, as

351 well as the non-applicability of "project ownership" category to wind farms located in the

352 communal land regimen.

353

354 Table 2- Most mentioned impacts within categories of community benefits schemes.

\begin{tabular}{|c|c|c|c|c|c|c|c|c|c|}
\hline \multirow[t]{2}{*}{ Category } & \multirow[t]{2}{*}{ Most mentioned impacts } & \multicolumn{7}{|c|}{ Interviewees } & \multirow[t]{2}{*}{ Relevant Quotes } \\
\hline & & 1 & 2 & 3 & 4 & 5 & 6 & 7 & \\
\hline $\begin{array}{l}\text { Community } \\
\text { Funds }\end{array}$ & - Regular payment (anual rent) & $*$ & $*$ & * & $*$ & $*$ & $*$ & $*$ & \multirow{13}{*}{$\begin{array}{l}\text { "...income resulting from leasing location site, } \\
\text { is being channeled towards social } \\
\text { infrastructures." (Interviewee 1) } \\
\text { "(...) our biggest benefit was on a financial } \\
\text { level, because it allowed to invest in new } \\
\text { infrastructures and to improve others already } \\
\text { existing. Before this would not be possible } \\
\text { because we lacked income. These are remote } \\
\text { areas, that do not have that sort of funds." } \\
\text { (Interviewee 5); }\end{array}$} \\
\hline \multirow{8}{*}{$\begin{array}{l}\text { Benefits in } \\
\text { kind }\end{array}$} & -Accessibilities provision or improvement & $*$ & $*$ & $*$ & $*$ & $*$ & $*$ & $*$ & \\
\hline & - Social infrastructure & $*$ & $*$ & * & $*$ & $*$ & $*$ & $*$ & \\
\hline & $\begin{array}{lll}\text {-Facility enhancements } & \text { (repair local } \\
\text { buildings) }\end{array}$ & & & * & $*$ & & & & \\
\hline & $\begin{array}{l}\text {-Environmental improvements } \\
\text { (reforestation) }\end{array}$ & & $*$ & $*$ & & $*$ & $*$ & $*$ & \\
\hline & -Wood supply to Commission members & & & & & & & $*$ & \\
\hline & - Rental of local buildings & $*$ & & & & & & & \\
\hline & $\begin{array}{l}\text {-Invest in other commercial activities } \\
\text { (tourism) }\end{array}$ & & & * & $*$ & * & & & \\
\hline & - Donations & & & * & & * & & * & \\
\hline \multirow{2}{*}{$\begin{array}{l}\text { Local } \\
\text { Employment } \\
\text { Direct }\end{array}$} & $\begin{array}{l}\text {-Local labor supply for construction } \\
\text { phase }\end{array}$ & & & & & & & \\
\hline & - Local labor supply for operational phase & $*$ & & * & & & & & \\
\hline \multirow{2}{*}{$\begin{array}{l}\text { Local } \\
\text { Employment } \\
\text { Indirect }\end{array}$} & $\begin{array}{l}\text { - Local labor supply for investment in } \\
\text { social infrastructure }\end{array}$ & $*$ & $*$ & $*$ & $*$ & * & $*$ & \multirow[t]{2}{*}{ * } & \\
\hline & $\begin{array}{l}\text {-Local labor supply for investments in } \\
\text { environmental improvement }\end{array}$ & & & * & & & & & \\
\hline
\end{tabular}

$355 *$ *Acknowledged impact

356

357 Therefore, all identified categories have been acknowledged by local stakeholders, with

358 some benefits clearly having a more significant expression such as regular payment;

359 provision and improvement of local infrastructure and social infrastructure; and indirect

360 employment in contrast to reforestation; tourism; donations or direct employment

361 generation. 
362 Nevertheless, these less mentioned benefits within each category, have also contributed

363 to make a distinction from previous studies and existing literature, showing that impacts

364 and population concerns are strongly related to the local specificities and needs.

\subsection{Stakeholder's perceptions of negative impacts}

367 Regarding negative impacts, and as patent in Table 3, most mentioned impacts with 368 potential adverse effect were either nonexistent or, if they were acknowledged by the 369 interviewees, they were mostly not perceived as a negative repercussion, as stated by

370 Interviewee 1 and Interviewee 3 concerning visual impact.

371 The interviewees also showed interest and concern over some aspects, namely impact on 372 local economic activities and noise emissions, as stated by Interviewee 7. However, none 373 of the represented commissions ever received complaints regarding negative impacts 374 from wind energy parks.

376 Table 3- Main referenced concerns with adverse impacts perceived by interviewees.

\begin{tabular}{|c|c|c|c|c|c|c|c|c|}
\hline \multirow[t]{2}{*}{ Category } & \multicolumn{7}{|c|}{ Interviewees } & \multirow[t]{2}{*}{ Relevant Quotes } \\
\hline & 1 & 2 & 3 & 4 & 5 & 6 & 7 & \\
\hline Landscape and visual impact & * & $*$ & $*$ & $*$ & $*$ & $*$ & $*$ & \multirow{12}{*}{$\begin{array}{l}\text { "(...) in our case, I do not think } \\
\text { we will have visual impact } \\
\text { because wind parks are located } \\
\text { very far away from the village } \\
\text { (about } 3 \mathrm{~km}) \text {. From residential } \\
\text { areas it will not be even possible } \\
\text { to see it. We (village) are located } \\
\text { in the lower part of the mountain, } \\
\text { and the wind park at a very long } \\
\text { distance on top, therefore it will } \\
\text { not be visible (...)". (Interviewee } \\
\text { 1); } \\
\text { "(..) people get easily used to } \\
\text { visual impact, as long as there is } \\
\text { interest and benefit involved. } \\
\text { People recognize that benefits } \\
\text { largely surpass disadvantages, at } \\
\text { least that is what I've heard } \\
\text { people say." (Interviewee } 3 \text { ); } \\
\text { "I used to be a shepherd and I } \\
\text { used to take my cattle grazing to } \\
\text { the area where now the wind park } \\
\text { is located, and initially it was a } \\
\text { big shock to see all the people that } \\
\text { now could access what used to be } \\
\text { a difficult access area, and } \\
\text { walking on grazing areas }\end{array}$} \\
\hline Noise emission impact & $*$ & $*$ & $*$ & * & $*$ & $*$ & $* *$ & \\
\hline Wildlife impact & $*$ & $*$ & $*$ & $*$ & $*$ & $*$ & $*$ & \\
\hline $\begin{array}{l}\text { Land occupation and usage } \\
\text { impact }\end{array}$ & $* *$ & $*$ & $*$ & * & * & $*$ & $*$ & \\
\hline Shadow flicker effect & ** & * & * & * & * & * & * & \\
\hline Electromagnetic interferences & $*$ & * & * & * & $*$ & * & $*$ & \\
\hline \multicolumn{8}{|l|}{ Socio-e } & \\
\hline - Property value & $*$ & * & * * & $*$ & $*$ & $*$ & * & \\
\hline - Cattle grazing & * * & * & $*$ & * & * & $*$ & $* *$ & \\
\hline - Farming & ** & * & $*$ & $*$ & * & * & * & \\
\hline - Tourism & 米 & * & $*$ & $*$ & $*$ & * & * & \\
\hline Water resources impact & $*$ & $*$ & $*$ & $*$ & $*$ & $*$ & $*$ & \\
\hline
\end{tabular}




\begin{tabular}{|c|c|c|c|c|c|c|c|c|}
\hline & & & & & & & & $\begin{array}{l}\text { jeopardizing them." (Interviewee } \\
\text { 7). }\end{array}$ \\
\hline Air quality & * & * & * & * & * & $*$ & * & \\
\hline
\end{tabular}

380 Similarly, to positive impacts portrayed in Table 2, most of the discussed negative impacts associated to the environmental and socio-economic categories have been acknowledged by the interviewees. The negative aspects frequently reported in the literature such as landscape and visual impact; noise; wild life; land occupation and air quality have been discussed as possible concerns but those aspects were not necessarily negatively perceived by the majority of the interviewees. Aspects related to concerning socioeconomic activities with local expression in the region, such as cattle grazing or farming were also mentioned as an initial source of concern which ended up not being as significant as expected.

\section{Discussion of the results}

391 Regarding positive impacts, there was a predominance of community benefits in both quantitative and qualitative analyses over potential disadvantages, with a statistically significantly higher number of respondents (56.5\%) supporting that wind farm implementation brings benefits to local communities, against $43.5 \%$ who believe there are no benefits. According to the conducted interviews, the most mentioned benefits are consistent with some of the categories previously identified in the literature including "community funds", "benefits in kind", or "local employment" (see Table 2).

398 Stakeholder's perceptions and distribution of the most mentioned impacts within the categories of community benefit schemes were corroborated by collected questionnaire results. For instance, when asked to specify most important benefits, respondent's answers coincided with those mentioned by a large majority of interviewees, reporting job creation (40\%) and community benefit funds (23\%), along with some benefits in kind, mainly providing or improving access roads $(16 \%)$ as the most the most relevant benefits.

404 This is supported by Interviewee 2 quote: "The main advantage for us is the financial 405 benefit that is a compensation they give us resulting from the usage of land ("baldios"). 406 Then we also have infrastructure improvement, since to access wind farm location, 407 developers have to provide accessibilities, which is also reflected as a positive outcome 
for local community”. The extent of the potential impact of these projects in both social and economic dimension is also adequately described by Interviewee 5: “(...) here the

410 little income we had was from the forest, there was no other source of income. We were 411 talking about a yearly sum around 2 to 3 thousand euros, and now we are talking about 41240 to 50 thousand. It is a very big difference”. (Interviewee 5).

413 Notwithstanding, despite that the investment in social infrastructure had a statistically 414 lower response from the local residents (10\%), a more detailed analysis based on open415 ended interviews has revealed an interlinkage to employment generation category. For 416 the most part of the focal stakeholders, employment generation has been associated to the 417 way generated income is managed and redirected towards other investments, i.e. it has an 418 indirect nature. These results reflected that indirectly generated employment should be 419 emphasized, demonstrating a wide level of implementation contributing to local welfare, 420 which is line with Okkonen and Lehtonen (2015) and shows a rather positive vision 421 comparatively to findings in other cases as described for example in Munday et al (2011). 422 Interviewee 2 gave an example of a nearby village that was very much undeveloped, and 423 due to wind park implementation has now a retirement home that employed a total of 424 about 18 people, making a substantial difference in an isolated rural area with social 425 issues, namely aging and emigration of population as well as limited employment prospects. Nonetheless, despite the exposed connection, a large majority of the respondents still addressed employment generation as their main concern for the region.

428 Similarly, this conjoint analysis has allowed to focus other specific aspects from this case study, included in "other" benefits (11\%) such as reforestation that far from being considered one of the most relevant benefits is according to most interviewees a recurrent and controversial theme. Respondents had conflicting views regarding potential application of wind energy funds to forest resources, either willingly and consciously accepting this proposal or opposing it, preventing its application. Such resistance is a consequence of a combination of socio-economic and cultural background allied to misinformation and miscommunication issues that shape not only the perception about the project but also decision making towards application of funds. This is not unexpected outcome as other studies also concluded that consensus over how a community fund should be managed may never be fully possible (Aitken, 2010b). Regarding negative impacts, quantitative and qualitative data are generally on agreement. 
recognition by research participants that socio-economic benefits tend to be overvalued comparatively to negative impacts, which inevitably conditions their perceptions. Most of the negative impacts are not mentioned and if acknowledged are perceived as irrelevant case study.

445 Quantitative data shows that a minority of respondents (30\%) recognize the existence of 446 negative impacts. Noise is regarded as the most important negative impact, although only 447 mentioned by $20 \%$ of overall respondents. Likewise, most interviewees claimed not 448 having suffered of noise pollution. These results were consubstantiated by Tsouchlarakia 449 et al. (2009), with most negative perceptions being linked to aesthetic and noise impacts 450 despite a wide acceptance by local inhabitants. Interviewee 7 stated that although no complaints by local community have ever been reported concerning this issue, he in particular thinks that his village is somewhat affected by noise emissions, being influenced by the prevalent wind direction. Nonetheless measures were taken to reduce its negative effects. For instance, Interviewee 3 claimed that special care has been taken to control noise emissions during certain periods of the day during the construction phase, to avoid interference with highly ecologically sensitive areas.

457 Visual impact was also emphasized by less than $6 \%$ of the responses, while according to some interviewees it was not an important issue due to wind farm location and substantial distance to residential areas or verified but not negatively perceived. This is in line with Aitken (2010b) and Katsaprakakis (2012) findings, who concluded that the nearest communities to the wind farm were not necessarily the ones facing the greatest impact, because rocky areas tend to confine direct impact opposing flat areas tending to have more extensive impact areas, nearby residential areas. However, this case study was confined to one region and as such no generalization on this aspect can be attempted on this matter as the respondents' opinion may be influenced by the landscape attributes and sitting of the turbines (Molnarova et al., 2012).

467 Although Interviewees 3 and 6 share the opinion that construction of wind farms indirectly benefited local shepherds by facilitating access to grazing pastures, another Interviewee 7, disagrees and views this new accessibility to pastures as quite shocking and as potentially compromising these habitat's management. This restricted concern over impacts on local economic activities, namely interference with agricultural and shepherding is consubstantiated by an equally limited percentage (1.5\%) of all respondents. 
474 Both a majority of respondents to the questionnaire and interviewees were favorable to

475 wind power deployment. Anyway, there was a somewhat considerable percentage of 476 indecisive respondents, which highlighted the importance of timely access to accurate 477 information directed towards specific local communities' interests. This aspect is also 478 connected to changes in attitude towards project acceptability, since although a large 479 percentage of respondents were favorable to this kind of project a few changes to initial 480 stance were registered. These results reinforce the importance an open and inclusive 481 participatory process. In addition, an important claim brought to the debate by the 482 interviewees was related to the lack of negotiation skills and knowledge of the 483 communities representatives when working with the promoters. This issue is also debated 484 in the literature calling attention to the benefits of residents' involvement in RES projects 485 facilitated by professionals in order to accompany negotiation process, ensuring 486 advisement and support for local communities (see for example Rogers et al. 2008).

487 According to the interviewees, resorting to an independent entity would also contribute 488 to establish a missing connection between national and local authorities ensuring a more 489 successful outcome to revenues, The mention by interviewees of the need to establish a 490 link between national and local authorities has been considered focal and very accurate, 491 as other authors (see Allen et al, 2012) have mentioned it as being vital to implement 492 RES projects at a local scale.

\section{Conclusions}

496 The presented case study resorted to a mixed methodology and has allowed to perceive a 497 positive attitude of local residents' opinion and stakeholders towards wind farms. This 498 community support seems mainly driven by the perceived benefits resulting from wind 499 farm deployment. This is in line with the previous study from Ribeiro et al (2014) also 500 for Portugal, who showed that local social benefits can play a major role on the acceptance 501 of these plants.

502 Therefore, there was a predominance of community benefits in both inquires over 503 potential disadvantages, with stakeholder's perceptions and distribution of most 504 mentioned impacts within identified categories of community benefit schemes, encompassing "community funds", "benefits in kind" and "local employment" being 
506 corroborated by collected questionnaire results. Regarding the most important benefits,

507 respondent's answers from the quantitative analysis coincided with those mentioned by a 508 large majority of interviewees, reporting job creation and community benefit funds, along 509 with some benefits in kind, mainly providing or improving access roads. Emphasis to 510 employment generation and community funds reflect the relevance of present local socio511 economic and cultural context play when addressing benefits or social costs ascribed to 512 RES projects and the results show how historical cultural practices can shape perceptions 513 of wind energy development.

514 Although a few negative effects were also reported both during interviews and 515 questionnaires, as in Frantál (2015) the amount of socio-economic benefits seems to play 516 a determinate role on the locals' attitudes towards wind farms.

517 The results of both questionnaires and interviews have illustrated how management of 518 community benefit schemes is connected to local specificities such as traditions and 519 socio-cultural background denoting the need to adopt a widespread integrative solution 520 involving various stakeholders within negotiation process, in order to achieve a more 521 consensual, future length appropriate outcome, reinforcing the importance of local 522 community perception's to achieve local sustainability. Based on the results some policy implications can be drawn from the study.

524 Firstly, and by far most the highest importance assigned to job creation either from direct 525 wind power projects or from socio-economic activities derived from the benefits assigned 526 to the local community. As Guo et al (2015) supported this should be seen as a sign of 527 the importance of prioritizing hiring local residents to increase the acceptance of these 528 wind farms.

529 Secondly, the sense of benefit sharing is evident for both local residents and stakeholders 530 although the relative importance assigned to the resulting investments or facilities is not 531 fully consensual reflecting the heterogeneous characteristics of the population. The socioeconomics impacts of re-investment of financial returns directly assigned to local

533 community demonstrate the relevance of the implementation of fair benefit sharing 534 mechanisms to ensure public acceptance and effective local development.

535 Thirdly, negatives aspects are related to several factors but the noise issue remains as the 536 most important one closely followed by landscape concerns. Even if for the moment these 537 negative factors do not seem to be enough to overweight the perceived socio-economic 
538 benefits, decisions makers should not overlook them as possible drivers of conflicts and 539 negative reactions with important effects across the population and affecting future 540 projects acceptance.

541 Fourthly, communication issues and lack information still remain as major drawbacks for 542 the involvement of local population on energy decision making. Local population

543 frequently lacks the technical background, time and negotiation skills to engage in these 544 processes demonstrating the importance of creating mechanisms to obtain external 545 professional support.

546 As for the proposed research approach, this study showed that combining both qualitative 547 and quantitative methods brings additional information for the impact evaluation allowing to access the general views of the population but also to match the results with the socioeconomic and cultural background of local population.

550 Finally, it is worth pointing out that being the results derived from a single case study 551 they suffer from potential limitations on any attempt of generalization. Nevertheless, the selected case presents population characteristics similar to most locals where wind farms are installed in Portugal and even in the Iberian region. These common characteristics, provide then some confidence on the general conclusions and on the possibility of sharing valuable foundations to future studies on social impact assessment of RES projects at local scale.

\section{References}

1. Aitken, M. (2010a) Why we still don't understand the social aspects of wind power: A critique of key assumptions within the literature. Energy Policy, Volume 38 (4), Pages 1834-1841. http://dx.doi.org/10.1016/j.enpol.2009.11.060.

2. Aitken, M. (2010b) Wind Power and Community Benefits: Challenges and Opportunities. Energy Policy, Volume 38(10), Pages 6066-6075. http://dx.doi.org/10.1016/j.enpol.2010.05.062

3. Allen, J., Sheat, R.W., Chavez-Diaz, R. (2012) Community - based Renewable Energy in the Lake District National Park - local drivers, enablers, barriers and solutions. Local Environment: The International Journal of Justice and Sustainability. Volume 17 (3), Pages 261-280. http://dx.doi.org/10.1080/13549839.2012.665855

4. Bamberger, M. (2012) Introduction to mixed methods in impact evaluation. Impact Evaluation Notes No. 3. August 2012. InterAction.

5. Bell, D., Gray, T., Hagget, C. (2005). The 'Social Gap' in Wind Farm Siting Decisions: Explanations and Policy Responses. Environmental Politics. Volume 14 (4), Pages 460-477. http://dx.doi.org/10.1080/09644010500175833

6. Botelho, A. Pinto, L., Lourenço-Gomes, L., Valente, M., Sousa, S. (2016) Social sustainability of renewable energy sources in electricity production: An application of the contingent valuation method. Sustainable Cities and Society, Volume 26, Pages 429-437. http://dx.doi.org/10.1016/j.scs.2016.05.011.

7. Cameron, L., van der Zwaan, B. (2015) Employment factors for wind and solar energy technologies: A literature review. Renewable and Sustainable Energy Reviews, Volume 45, Pages 160-172. http://dx.doi.org/10.1016/j.rser.2015.01.001. 
8. de Sena, L.A., Ferreira, P., Braga, A.C. (2016). Social acceptance of wind and solar power in the Brazilian electricity system. Environment, Development and Sustainability. Volume 18 (5), Pages 1457-1476. http://dx.doi.org/10.1007/s10668-016-9772-0.

9. Del Rio, P., Burguillo, M. An empirical analysis of the impact of renewable energy deployment on local sustainability. Renewable and Sustainable Energy Reviews. Volume13 (6-7), Pages13141325. http://dx.doi.org/10.1016/j.rser.2008.08.001

10. Delicado, A., Figueiredo, E., Silva, L. Community perceptions of renewable energies in Portugal: Impacts on environment, landscape and local development. Energy Research \& Social Science, Volume 13, Pages 84-93. http://dx.doi.org/10.1016/j.erss.2015.12.007.

11. DGEG-Direção Geral de Energia e Geologia (2015). Balanço Energético Sintético 2014. (in Portuguese).

12. Ejdemo, T., Söderholm, P. (2015) Wind power, regional development and benefit-sharing: The case of Northern Sweden. Renewable and Sustainable Energy Reviews, Volume 47, Pages 476485. http://dx.doi.org/10.1016/j.rser.2015.03.082.

13. Ek, K., Matti, S. (2015) Valuing the local impacts of a large scale wind power establishment in northern Sweden: public and private preferences toward economic, environmental and sociocultural values. Journal of Environmental Planning and Management Volume 58 (8),Page 1327-1345 $\square$ http://dx.doi.org/10.1080/09640568.2014.922936.

14. Frantál, B. Have Local Government and Public Expectations of Wind Energy Project Benefits Been Met? Implications for Repowering Schemes. Journal Of Environmental Policy \& Planning, Volume. 17 (2). http://dx.doi.org/10.1080/1523908X.2014.936583

15. Gorayeb, A., Brannstrom, C. (2016). Toward participatory management of renewable energy resources (wind-farm) in northeastern Brazil. Mercator (Fortaleza), Volume15 (1), Pages 101115. http://dx.doi.org/10.4215/RM2016.1501.0008

16. Guo, Y. Ru, P., Su, J., Anadon, L.D. (2015) Not in my backyard, but not far away from me: Local acceptance of wind power in China. Energy, Volume 82, Pages 722-733. http://dx.doi.org/10.1016/j.energy.2015.01.082.

17. Hale, D.C.; Astolfi, D. (2007). Evaluating Education and Training Services: A Primer. (9). Florida. Retrieved from:http://www.charlesdennishale.com/books/eets_ap/9_Qualitative_Research_Designs.pdf

18. INEGI - Instituto de Ciência e Inovação em Engenharia Mecânica e Engenharia Industrial (2015). Wind Farms in Portugal December 2015.

19. Katsaprakakis, D.A (2012) A review of the environmental and human impacts from wind parks.A case study for the Prefecture of Lasithi. Renewable and Sustainable Energy Reviews, Volume 16 (5), Pages 2850-2863. http://dx.doi.org/10.1016/j.rser.2012.02.041

20. Khorsand, I., Kormos, C., MacDonald, E., Crawford, C. (2015) Wind energy in the city: An interurban comparison of social acceptance of wind energy projects. Energy Research \& Social Science, Volume 8, Pages 66-77. http://dx.doi.org/10.1016/j.erss.2015.04.008.

21. Lima, Fátima; Ferreira, Paula; Vieira, Filipa (2013) "Strategic impact management of wind power projects" Renewable and Sustainable Energy Reviews, Vol. 25, pp. 277-290. https://doi.org/10.1016/j.rser.2013.04.010

22. Molnarova, K., Sklenicka, P., Stiborek, J., Svobodova, K., Salek, M., Brabec, E. (2012) Visual preferences for wind turbines: Location, numbers and respondent characteristics. Applied Energy, Volume 92, Pages 269-278. http://dx.doi.org/10.1016/j.apenergy.2011.11.001

23. Mendes, L.; Costa, M.; Pedreira, J.M.(2002). A Energia Eólica e o Ambiente- Guia de Orientação para a Avaliação Ambiental (in Portuguese). Alfragide. Instituto do Ambiente Editions. (in Portuguese). Retrieved from:http://www.apambiente.pt/_zdata/Instrumentos/AIA/Guia_de_Orientacao_para_Avaliacao _Ambiental_PE.pdf 
24. Munday, M., Bristow, G., Cowell, R. Wind farms in rural areas: How far do community benefits from wind farms represent a local economic development opportunity? Journal of Rural Studies. Volume 27 (1), Pages 1-12. http://dx.doi.org/10.1016/j.jrurstud.2010.08.003

25. Okkonen, L., Lehtonen, O. (2015) Socio-economic impacts of community wind power projects in Northern Scotland. Renewable Energy, Volume 85, Pages 826-833. http://dx.doi.org/10.1016/j.renene.2015.07.047.

26. Ortega, M., del Río, P., Ruiz, P., Thiel, C. (2015) Employment effects of renewable electricity deployment. A novel methodology. Energy, Volume 91, Pages 940-951. http://dx.doi.org/10.1016/j.energy.2015.08.061.

27. Presidência do Conselho de Ministros (2013). Resolução do Conselho de Ministros n. ${ }^{\circ}$ 20/2013. Diário da República, 1. ${ }^{\mathrm{a}}$ série - N. ${ }^{\circ} 70-10$ de abril de 2013 (in Portuguese).

28. REN- Redes Energéticas Nacionais (2015) “Dados técnicos 2015” (in Portuguese).

29. Ribeiro, F. Ferreira, P., Araújo, M., Braga, A.C. (2014). Public opinion on renewable energy technologies in Portugal. Energy, Volume 69, Pages 39-50. http://dx.doi.org/10.1016/j.energy.2013.10.074.

30. Ribeiro, F.; Ferreira, P.; Araújo, M. (2011). The inclusion of social aspects in power planning. Renewable and Sustainable Energy Reviews, Volume 15 (9), Pages 4361-4369.

31. Rogers, J.C., Simmons, E.A., Convery, I., Weatherall, A. (2008) Public perceptions of opportunities for community-based renewable energy projects. Energy Policy, Volume 36, Pages 4217-4226.

32. Rubin, A. and Babbie, E. (1997).Research Methods for Social Work.3rd Edition. (pp. 1-405). Pacific Grove, California: Brooks/Cole Publishing Company

33. Sooriyaarachchi, T. M., Tsai, I., Khatib, S., Farid, A., Mezher, T. (2015) Job creation potentials and skill requirements in, PV, CSP, wind, water-to-energy and energy efficiency value chains. Renewable and Sustainable Energy Reviews, Volume 52, Pages 653-668. http://dx.doi.org/10.1016/j.rser.2015.07.143.

34. Tsouchlarakia, A.; Tsiropoulosa, M.; Serpetsidakisb, M. (2009) Visual impact evaluation of a wind park in a Greek island. Applied Energy, Volume 86 (4), Pages 546-553. http://dx.doi.org/10.1016/j.apenergy.2008.08.013

35. Walter, G. (2014) Determining the local acceptance of wind energy projects in Switzerland: The importance of general attitudes and project characteristics. Energy Research \& Social Science, Volume 4, Pages 78-88. http://dx.doi.org/10.1016/j.erss.2014.09.003. using GIS-assisted multi-criteria evaluation. Landscape and Urban Planning, Volume 138, Pages 20-31. https://doi.org/10.1016/j.landurbplan.2015.02.001. 